Article

\title{
Exploring Secondary Students' Alternative Conceptions about Engineering Design Technology
}

\author{
Anila Asghar ${ }^{1, *}$, Ying-Syuan Huang ${ }^{1} \oplus$, Kenneth Elliott ${ }^{2}$ and Yannick Skelling ${ }^{3}$ \\ 1 Department of Integrated Studies in Education, McGill University, Montreal, QC H3A 2M1, Canada; \\ ying.huang6@mail.mcgill.ca \\ 2 Independent Researcher, McGill University, Montreal, QC H3A 2M1, Canada; kelliott@videotron.ca \\ 3 Département de didactique, Université du Québec à Montréal (UQAM), Montreal, QC H2X 3R9, Canada; \\ skelling.yannick@gmail.com \\ * Correspondence: anila.asghar@mcgill.ca; Tel.: +1514-398-4527 (ext. 094194)
}

Received: 11 January 2019; Accepted: 18 February 2019; Published: 24 February 2019

check for updates

\begin{abstract}
This paper presents the assessment items that were developed by science and technology teachers in Québec to explore their students' alternative ideas about engineering design technology and technological systems. These assessment items were administered to Secondary Cycle One students in Francophone and Anglophone schools in Québec to elicit their ideas about the foundational technology concepts included in the science and technology curriculum. Students' responses are presented to share their alternative and scientific explanations. In addition, various approaches to facilitate a deeper understanding of scientific models and mechanistic reasoning in students are also discussed.
\end{abstract}

Keywords: science; technology; engineering; mathematics (STEM) education; engineering design technology; students' alternative conceptions; conceptual change; conceptual assessment items; inquiry-based science and technology; learner-centered pedagogy; assessment tool

\section{Introduction}

This paper aims to share the resources that we have developed in collaboration with secondary science and technology teachers in Québec to support the teaching of engineering design technology. To this end, we present the assessment tools that were developed by the teachers to elicit their students' alternative ideas about technology and technological systems. These assessment items were administered to Secondary Cycle One students (grades seven and eight) in Francophone and Anglophone schools in Québec to elicit their alternative ideas about the foundational technology concepts included in the science and technology curriculum in Québec. We hope that science educators will benefit from the tools that their fellow colleagues developed to facilitate the integration of science and technology while teaching the Québec Education Program. This paper is organized into five sections. First, we provide an overview of the Science and Technology program in Quebec. Then, we review the literature on students' intuitive or alternative conceptions in science. In the subsequent sections, we describe the study methods, present an analysis of the key findings focusing in secondary students' intuitive conceptions of technological systems, and discuss the pedagogical implications of this work, relative to the literature on conceptual change approaches to science and technology education.

The Québec Education Program (QEP) is a competency-based curriculum divided into six Subject Domains, with Mathematics, Science, and Technology being one of them [1]. Each subject has competencies that must be developed by the students through Elementary and Secondary school. The discipline-specific and cross-curricular competencies aim to develop students' intellectual 
capacities and appropriate social skills that will enable them to respond to complex changes in their environment [1]. According to the QEP,

One aim of a competency-based program is to ensure that students' learnings serve as tools for both action and thought, which is a form of action. Unlike a skill, which may be applied in isolation, a competency makes use of several resources and is itself used in fairly complex contexts. [2] (p. 4)

The content for each subject area for each cycle is defined by the QEP and is used to develop the competencies. One of the major changes introduced by the QEP to the curriculum of the science program was the introduction of technology education - to prepare students for modern society [3,4]. In fact, all of the compulsory science programs from Secondary One through Secondary Four are now named "Science and Technology". The QEP emphasizes that science and technology are intimately intertwined in the modern world and due to their intricate connections, it is not easy to draw concrete boundaries between the two domains [3] (p. 1).

Incorporating technical education into general education was part of a world-wide trend through the 1980s and 90s, supported by United Nations Educational, Scientific and Cultural Organization (UNESCO). Both the Canadian Council of Ministers of Education (CMEC) in their Common Framework of Science Learning Outcomes K to 12 as well as the American Association for the Advancement of Science (AAAS) in their landmark publication, Project 2061, strongly influenced the writing of the Science and Technology programs of the QEP. Prior to this movement, students who pursued technical education were directed to the workplace and those in general education, to higher education [4]. Using technology to teach science is well-researched-showing that technology-centered classrooms, can lead to effective science learning [5-10]. Engineering design is a key theme of QEP technology content [1]. Prior to the introduction of the QEP, all Secondary Three (grade nine) students took Introduction to Technology (ITT) [3]. Students worked in a woodworking lab developing engineering designs and building models. The QEP Science and Technology programs specifically integrated the essentials of ITT [11]. An integrated approach to teaching Science, Technology, Engineering, and Mathematics (STEM) is central to the QEP curriculum [12]. The STEM approach emphasizes the development of competencies related to mathematics, science, and engineering-based technology to develop students' scientific reasoning, critical thinking, and conceptual understanding by engaging in experimental inquiries [3]. Such inquiries encourage students to test their ideas by developing investigable questions, using organized observation, and devising procedures for their investigations. Through this process, they are expected to develop the skills to interpret and analyze their observations while drawing on logical arguments, when appropriate [3]. Furthermore, the STEM related competencies focus on "discerning patterns and relationships" in the data to understand the evidence that they collect.

The QEP highlights the relevance of science, technology, and mathematics to the evolving needs of society and the ways in which these fields have shaped modern society [5]. The QEP illuminates the common elements in these subject areas which focus on developing students' understanding, critical thinking, analytical reasoning, inquiry competency, and communication skills [3] (p. 186). Moreover, cultivating students' imagination, creativity and a desire to explore and discover is also emphasized as a significant element of STEM subjects. As explained in the QEP, scientific and technological literacy would enable youth to use scientific knowledge and skills appropriately and productively in their professional and personal lives. Schools are seen as key sites for developing students' abilities to achieve this key goal of public education in Canada [3].

The QEP Science and Technology program encompasses five scientific disciplines (chemistry, physics, biology, astronomy, and geology) and "various technological fields (e.g. mechanical design, medical, food and mining technology) studied in the context of cultural references" [3] (p. 225). This curriculum focuses on the following key competencies at the Secondary Cycle One level (grades seven and eight): (1) "Seeks answers or solutions to scientific or technological problems," (2) "Makes the most of his/her knowledge of science and technology," and (3) Communicates in the languages used in science and technology." The first competency focuses on developing students' inquiry skills as 
they actively engage in the process of asking questions and exploring possible solutions through "observations, hands-on activities, measurements, construction or experimentation, be it in a lab, in a workshop or in the real world" [3] (p. 226). The second competency focuses on the application of knowledge, particularly in real life situations. The students develop a deeper understanding of scientific concepts and technological models by analyzing how technical objects work [3]. The ability to effectively interpret and communicate scientific and technological knowledge using appropriate language is intimately connected to these competencies

Engineering-based technology provides a useful context for applying content knowledge as students engage in analyzing and designing complex systems [13-16]. Engineers are involved in such activities in real life settings when solving complex technological problems, improving manufacturing processes, building infrastructure, designing new devices (e.g., computers, electronic communication tools), and addressing socioenvironmental issues (e.g., waste and recycling management, public transit systems) [17] (pp. 370-371). The essential concepts and progression of learning goals for engineering-based technology in the QEP for Secondary Cycle One (grades seven and eight) focus on (a) graphical language, (b) mechanical engineering, (c) materials, and (d) manufacturing. Students are expected to learn and to represent the design of a technical object and its functional components. Graphical language focuses on explaining "the operation of a simple technical object by drawing a diagram illustrating the active forces and the resulting motion" [18]. Technical diagrams illustrate certain principles of simple machines (e.g., a lever or a wedge) and represent the construction of a technical object and the arrangement of its components.

Mechanical engineering for Secondary Cycle One focuses on forces and motion, technological systems, and engineering. Students are expected to learn about different types of motion, effects of a force, simple machines, different types of technological systems, key components of technological systems and their functions, and energy transformations in technological systems. Engineering includes basic mechanical functions of a technical object and motion transmission systems in technical objects.

In addition, students are expected to learn about different types of material resources, such as raw materials used in the industry, materials present in technical objects, the origins of these materials, and the tools that are used to manufacture technical objects. Understanding of the manufacturing process is also important for students at this level. For example, students should observe and critically analyze the structure of a technical object, the specifications involved in the design of that object, and its function in certain social, economic, and industrial environments. This process should enable the students to design and construct a prototype of a technical object or some components of that object [16]. Research suggests that developing a deeper and more meaningful understanding of students' scientific and technological concepts and processes requires an understanding of the conceptual models and resources that students bring to the science classroom. Below we discuss the literature on students' intuitive and alternative frameworks, and their role in science learning.

\section{Students' Intuitive or Alternative Conceptions in Science}

Researchers in all areas of science education have noted that students (and adults) often hold common sense beliefs that derive from their perceptual experiences and exploration of the physical world" [19-21]. Through a "continuous process of interaction between their cognitive system and the physical and cultural environment, human beings instinctively develop their explanations of natural phenomena" [22] (p. 553). Researchers argue that children's ideas are based on general abstractions from common experiences. They use this contextual knowledge to develop explanations in certain situations and in response to particular questions or problems in everyday life [23-26]. Children's intuitive or alternative conceptions tend to be very different from scientific conceptions and may often contradict the abstract scientific models [27-29]. Research shows that students' alternative explanations may persist even after students are exposed to the scientific models during formal instruction and continue to affect students' science learning [22,23,30-34]. Indeed, research indicates that deeply held 
intuitive or common-sense conceptions are fairly stable and cannot be completely replaced by the scientific conceptions through science instruction. Rather, alternative conceptions may co-exist with the scientific models [28,29,35]. Dawson (2014) argues that learners may construct a "conceptual profile" which encompasses their alternative conceptions along with the scientific models [35] (p. 389).

Ideas firmly held by students will directly impact science teaching and the ability of science instructors to help their students to develop a deeper understanding of accepted scientific models. At the same time, traditional science instruction tends to ignore students' own ideas and beliefs and is mostly unsuccessful in developing a robust understanding of accepted scientific models [36,37]. Recognizing students' common-sense ideas and the ways in which students use them to make sense of scientific and technological phenomena is of paramount importance in science education $[13,38,39]$. Therefore, eliciting and attending to students' alternative conceptions must be an integral component of science instruction.

Inquiry-based approaches to learning science encourage the learners to actively construct and apply scientific knowledge through problem-solving [40]. In this process, students construct new scientific knowledge by assimilation — adding ideas to their existing framework —or accommodation-restructuring their cognitive frameworks to make sense of and integrate the new concepts [41]. Thus, it is particularly important for students to examine and compare their own models vis-à-vis the accepted scientific models that they learn in school $[28,29,35,38]$. Scientific paradigms must be introduced carefully, especially in those instances where common sense beliefs are at odds with the scientific perspective $[42,43]$. As a consequence, it is vital that we provide teachers and curriculum developers with evidence of commonly held ideas. A variety of anthropological studies have attempted to develop an understanding of student viewpoints [44], as well as a clear picture of the intersection between alternative conceptions and instruction [45-48]. Science teachers need to understand the student perspective before attempting to teach new scientific ideas. Research suggests that the most effective instruction is based on initial consideration of students' prior conceptions, instructional goals, and careful alignment of pedagogical practice with those goals. Effectiveness of these instructional approaches can be determined through the use of conceptual assessment tools that are aligned to the instructional goals [46,49]. Eliciting students' thinking through formal diagnostic testing or open-ended verbal and pictorial student descriptions can provide very useful information to science teachers how to inform their instruction. In this paper, we share a collaborative project that brought together science and technology teachers and consultants from three school boards and university researchers in Québec to develop assessment tools for use in local schools.

With the implementation of the QEP science and technology programs, many science teachers found themselves unfamiliar with how to integrate technology into the science curriculum [50]. They needed ongoing professional training and support so that they could teach technology content and encourage their students to engage in technology and engineering design activities. The Québec Ministry of Education sponsored Centre de Developpement Pédagogique (CDP) and the English counterpart, Science and Technology Implementation Committee (STIC) provided teachers with activities so that students and teachers could work with technological objects that are familiar and relevant to students [51].

The authors were engaged in a collaborative professional development project to support science and technology teachers and to connect research in science education with professional practice in schools in Québec. This project was unique as it was collaboratively developed by science and technology education consultants and university faculty from Francophone and Anglophone sectors in response to science teachers' professional needs. Science teachers and consultants from three partner school boards (two Anglophone and one Francophone School Board) worked with faculty members from McGill and Université du Québec à Montréal over three years to achieve the following objectives: (1) Professional development of Secondary Cycle One (grades seven and eight) science and technology teachers to promote their students' conceptual development, technology skills, and problem-solving competencies and (2) Development of appropriate assessment questions to 
identify students' alternative conceptions related to science and technology concepts included in the QEP. The project team drew on current developments in science education research and practice to create assessment items and inquiry-based activities to foster students' engagement and learning. The assessment tools were developed in French and English for teachers from Francophone and Anglophone schools.

Science teachers worked together, in collaboration with the research team, to study and adapt existing assessment items from various sources, such as the American Advancement of Science (AAAS) and other conceptual inventories focusing on different science concepts for instructional purposes. Other practitioners and researchers can access the assessment item bank and the prevalent alternative conceptions in science available on the AAAS site. The assessment items were organized in accordance with the Progression of Learning goals and the four Worlds (i.e., the Material World, the Living World, Earth and Space, and the Technological World) in the QEP. The Ministry of Education has organized the learning content included in the QEP for each school subject. Progression of Learning goals guide teachers' instructional plans regarding the content that students are required to learn in a particular year. A distinctive feature of our project is that teachers and science education consultants from partner school boards played a key role in adapting existing, and developing new, assessment questions. The content validity of the questions was established by content experts in STEM disciplines. For example, scientists and engineers examined the questions relevant to their expertise in physics, chemistry, biology, technology, and earth and space science. Selected questions were also piloted by the teachers in their classrooms to elicit students' thinking about different natural phenomena, to ascertain the readability level, and to gather students' feedback on the clarity of the questions. The questions were further refined in light of this feedback. The questions were developed in French and English and addressed most of the essential concepts in science and technology included in the curriculum.

\section{Methods}

This paper presents selected technology assessment questions that teachers can to elicit their students' initial understandings of principles of engineering and technical design and to plan their instruction in response to students' alternative ideas. Notably, the development of technology items is an innovative contribution of this project. While the literature offers a vast amount of assessment items and conceptual inventories focusing on science (physics, chemistry, biology, geology, astronomy) concepts to diagnose students' misconceptions and to inform science instruction, there is a dearth of appropriate and efficient assessment tools to examine and track students' understanding of engineering and technology concepts. Science teachers often rely on rubrics to assess their students' technology skills during and after instruction. It is essential to gain an understanding of students' alternative ideas to effectively address their prior ideas through instruction. In this article, we share a set of questions related to specific technology concepts (e.g., forces and motion, simple machines, and technological systems) that were developed by practitioners and academics in science and technology education during our collaborative professional development model.

As noted earlier, the technology assessment items addressed common difficulties that the teachers and technology consultants had encountered while teaching technology concepts and skills to their students. More specifically, the distractors incorporated prevalent misconceptions of students which the teachers had discovered in their classrooms (all questions are in a multiple-choice format). The science teachers and consultants who participated in this collaborative project developed an efficient assessment tool using the multiple-choice format to elicit their students' intuitive notions. They can use assessment items creatively in their classrooms. For example, teachers could initiate a discussion in the classroom to encourage their students to further explain their reasoning and to become aware of the ideas that they bring to the classroom.

Engineering and technology experts reviewed these assessment items to establish content validity. Furthermore, the project team reviewed, revised, and refined these assessment questions in several face-to-face meetings, item by item, with the aim of achieving consensus about these questions. The 
technological concepts in these items were aligned with the Progression of Learning goals in the science and technology curriculum in the QEP. Afterwards, all items from the consensus version were translated from English into French by a native French bilingual speaker who was a doctoral student at the Faculty of Education Sciences, Université du Québec à Montréal. The translations were reviewed by two technology education experts who were also bilingual speakers and had extensive experience of teaching science and technology in primary and secondary schools in Québec. The final translations were reviewed once again by the third author to compare and check for any discrepancies in the French and English versions. When differences were noticed, the most appropriate wording for the Québec context was jointly agreed upon by the third author and the technology education experts. The final version was then given to the project team teachers to examine the clarity and appropriateness of these items for secondary students.

The questions that are presented in this paper cover the topics of forces and motion, manufacturing, technological systems, and engineering. These items were administrated to Secondary Cycle One students via GoogleForm in selected public Francophone and Anglophone schools in Quebec. In total, the questions were answered by 126 students in grades seven and eight (37 Francophone and 89 Anglophone students). The technology items and students' responses are presented below. Importantly, our analysis illuminates students' intuitive reasoning in relation to basic technology concepts and problems. If these intuitive ideas are not probed and addressed upfront in the classroom, they can continue to interfere with students' learning. We hope that science teachers and teacher educators can use these questions to elicit their students' intuitive understandings of technology, to inform their pedagogical decisions to address intuitive or alternative conceptions, and to examine changes in students' conceptions before and after instruction. These questions will also help teachers assess the ways in which students apply scientific concepts to solve technological problems.

\section{Analysis of Students' Intuitive Conceptions of Technological Systems}

Herein, we present responses to selected questions to illuminate students' conceptions of technology and technological systems. Students' responses reveal several areas that science and technology teachers need to focus on, when designing their lessons on technology, to foster a meaningful understanding of engineering-based technology in students.

\subsection{Intuitive Notions of Technology and Technical Objects}

The majority of the Secondary Cycle One students in our sample seemed to understand the difference between natural and designed objects (see Figure 1a). Around $90 \%$ of the students identified the natural objects which are not altered by human beings. However, a few still thought that a glass bottle and a granite countertop are made of materials that are not changed by humans. Students were also asked to identify the technical objects in the question below. Interestingly, only about a quarter of the students thought that a pencil, a knife, and a smart phone are technical objects (see Figure 1b). Approximately half of the students only considered a smart phone as a technical object. It seems that many students tend to think that complex electronic products are technical objects, whereas simple and commonly used technical objects are not considered as technological products.

Another question revealed students' notions about the characteristics of technical objects (see Figure 2a). Only about a quarter of the students thought that a technical object is conceived and manufactured by humans and meets one or more needs, where as many students thought that using electricity is an important characteristic of technical objects. Similarly, when asked what technology is, approximately $30 \%$ of the students associated electricity with technology (see Figure $2 \mathrm{~b}$ ). Only less than half of the students understood technology as a process used in making a technical object. More than $15 \%$ of the students also thought that technology means machines that are used for communication. Interestingly, some students perceived technology as the use of computers only. Students' intuitive understanding of technology seems to be influenced by the pervasive use of electronic devices, such as computers, tablets, smart phones, etc. 


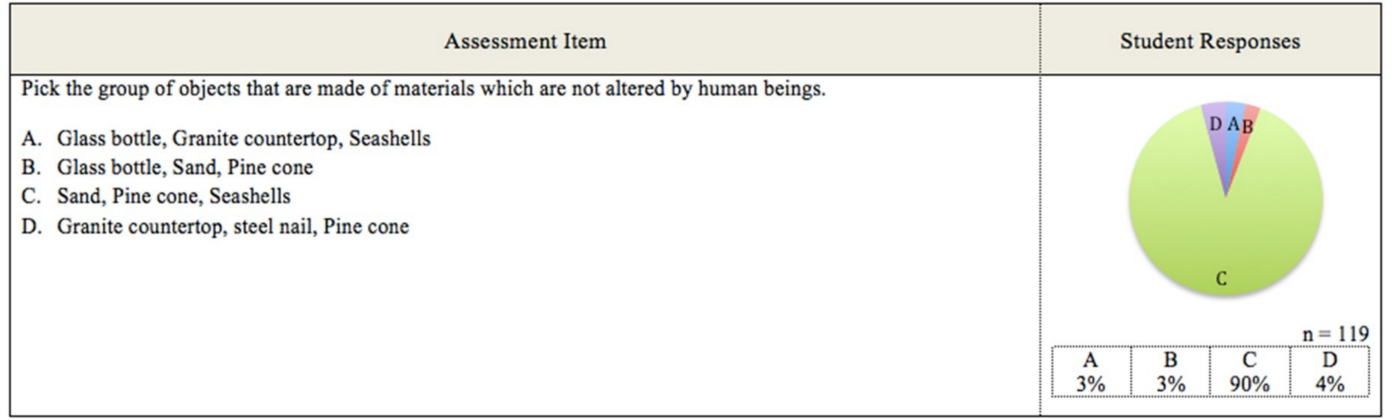

(a)

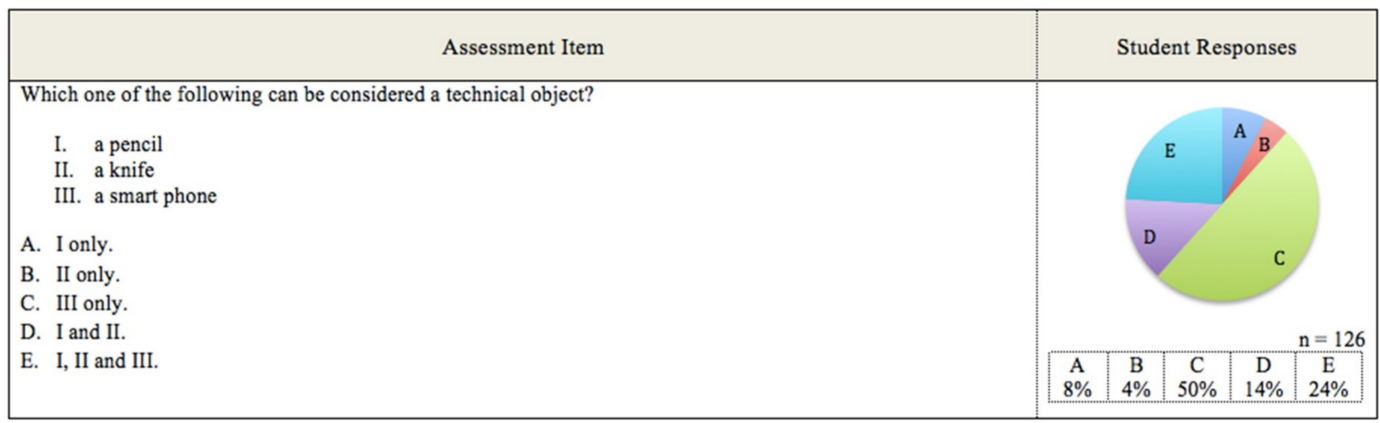

(b)

Figure 1. Students' Notions of Technical Objects. (a) Technical vs. Natural Objects; (b) Technical Objects.

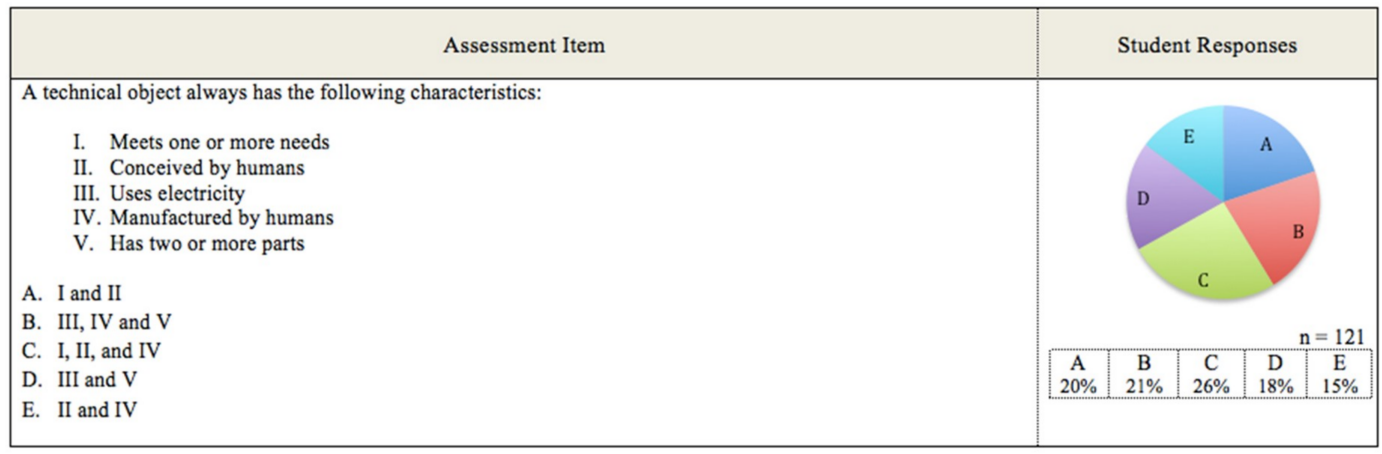

(a)

\begin{tabular}{|c|c|c|c|c|}
\hline Assessment Item & \multicolumn{4}{|c|}{ Student Responses } \\
\hline \multirow{7}{*}{$\begin{array}{l}\text { What is technology? } \\
\text { A. Something that uses electricity. } \\
\text { B. A process used in making a technical object. } \\
\text { C. The use of computers. } \\
\text { D. Machines that communicate with each other. }\end{array}$} & \multirow{6}{*}{\multicolumn{4}{|c|}{$\mathrm{n}=119$}} \\
\hline & & & & \\
\hline & & & & \\
\hline & & & & \\
\hline & & & & \\
\hline & & & & \\
\hline & $\begin{array}{c}\mathrm{A} \\
30 \%\end{array}$ & $\begin{array}{c}\mathrm{B} \\
45 \%\end{array}$ & $\begin{array}{c}\mathrm{C} \\
7 \%\end{array}$ & $\begin{array}{c}\mathrm{D} \\
18 \%\end{array}$ \\
\hline
\end{tabular}

(b)

Figure 2. Students' Notions of the Characteristics of Technical Objects. (a) Technical Objects and their Characteristics; (b) Technology. 


\subsection{Intuitive Notions of Simple Machines}

While children's and adult's alternative conceptions about scientific phenomena have been well documented in the literature, a few studies have looked at children's mechanistic reasoning in relation to technological systems. Developing students' mechanistic and logical reasoning is central to K-12 STEM curricula (MELS, AAAS, NGSS). It is important to explore children's mechanistic reasoning as it illuminates how they understand the cause and effect relationships and underlying mechanisms in technological systems. In addition, mechanistic reasoning reveals how they make sense of the relationship between the structure and function of a technical object or a mechanical device. Simple machines, such as gears and pulley systems can serve as useful tools to explore children's mechanistic reasoning. A better understanding of children's reasoning about the mechanisms underlying these systems can help to develop a robust understanding of advanced concepts, such as mechanical advantage, torque, ratio in students [14,16]. Another advantage of gears and pulleys is that students can directly observe their arrangement and how they transmit motion. Furthermore, a thorough investigation of how these simple machines work can also foster the development of students' understanding of cause and effect relationships. The development of causal reasoning would enable students to understand more complex systems and their underlying mechanisms [14].

The majority of the students in this study (over $82 \%$ ) correctly represented the motion of the gears in a gear system. Only about $18 \%$ had alternative ideas about the direction of the movement (see Figure 3). Similarly, when responding to the following two questions (see Figure $4 a, b$ ), $90 \%$ of the students correctly indicated the direction of movement in a simple gear system, which suggests that, based on their perceptual experiences, students are intuitively able to understand and make correct predictions about the motion of gears.

However, when asked about the rate of speed of gears with different number of teeth (and size), about two-thirds of the students demonstrated alternative conceptions about the rotational speed of a gear set (see Figure 5). On the other hand, one-third of the students had an intuitive understanding of how gear ratios work in terms of their speed of rotation. Calculating the gear ratio based on the number of teeth on a gear to predict an increase or reduction in the rotational speeds of gears in a system is a basic concept in mechanical engineering [52]. The pulley is an important simple machine. Pulleys serve to change the direction and decrease the amount of the force that is needed to move an object. Pulleys help in lifting heavy objects and are used in buildings, flagposts, boats, bicycle gears, elevators, cranes, etc.

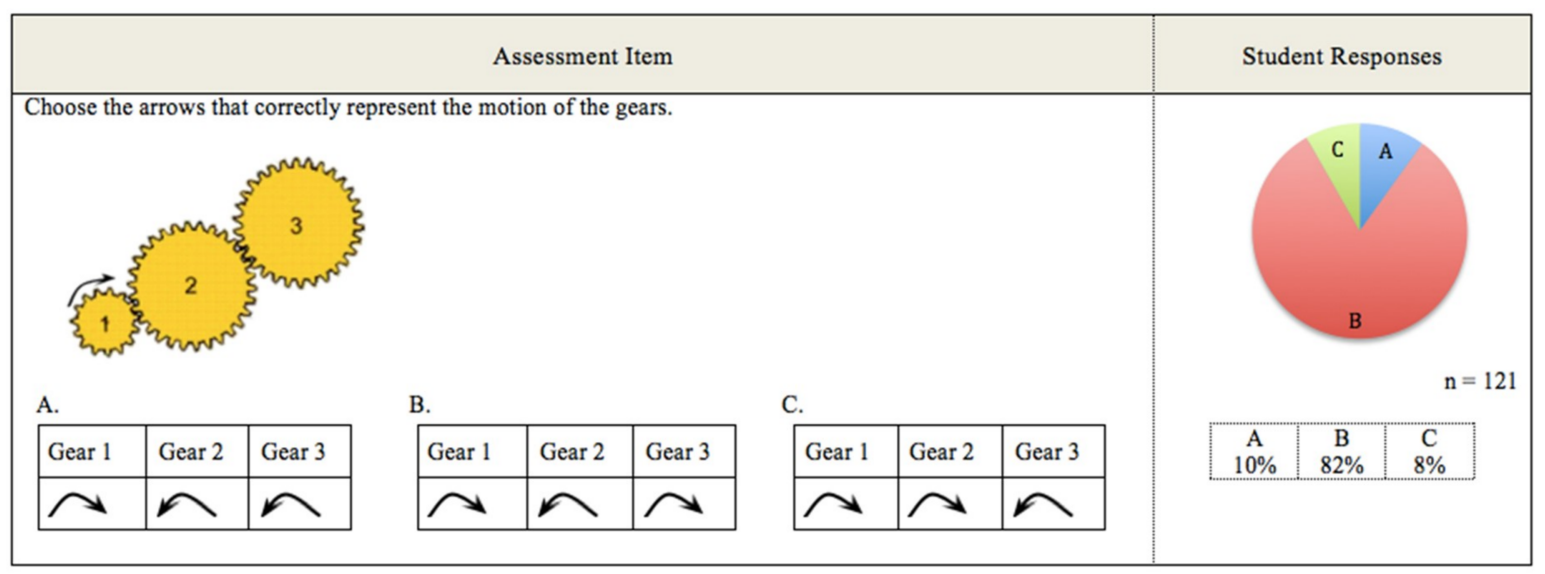

Figure 3. Students' Intuitive Notions of Simple Machines. 


\begin{tabular}{|l|l|}
\hline \multicolumn{1}{|c|}{ Assessment Item } & \multicolumn{2}{|c|}{ Student Responses } \\
\hline The left wheel is rotating clockwise. In which direction will the right gear turn? & \\
\hline & \\
A. Clockwise. & \\
B. Counter-clockwise. & \\
\hline
\end{tabular}

(a)

\begin{tabular}{|l|l|}
\hline \multicolumn{1}{|c|}{ Assessment Item } & Student Responses \\
\hline The top wheel is rotating clockwise. In which direction will the bottom wheel turn? & \\
\hline A. Clockwise. & \\
B. Counter-clockwise. & A \\
\hline
\end{tabular}

(b)

Figure 4. Students' Notions of the Motion of the Gears in a Gear System. (a) Direction of Movement in a Gear System; (b) Rotation in a Gear System.

\begin{tabular}{|l|c|}
\multicolumn{1}{|c|}{ Assessment Item } & Student Responses \\
\hline The left gear is rotating clockwise. At which speed will the right gear turn? & \\
A. At the same speed as the left gear. & \\
B. Faster than the left gear. \\
C. Slower than the left gear.
\end{tabular}

Figure 5. Students' Notions of the Rotational Speed of a Gear Set.

When asked to explain why the elastic band was crossed in a pulley system, approximately, 29\% of the students said that it changes the direction of rotation (see Figure $6 a$ ). About $71 \%$ students, however, demonstrated their alternative conceptions while responding to this question. They thought that the elastic was crossed to add to tension to the elastic or to reduce the speed of the movement. In the same way, about $31 \%$ of the students intuitively explained that different sizes of pulleys are used in a pulley system to change the speed of the movement (see Figure 6b). The majority of the students, however, had alternative ideas about the function of size as they thought that different sizes of pulleys help in changing the tension or the direction of the movement. 


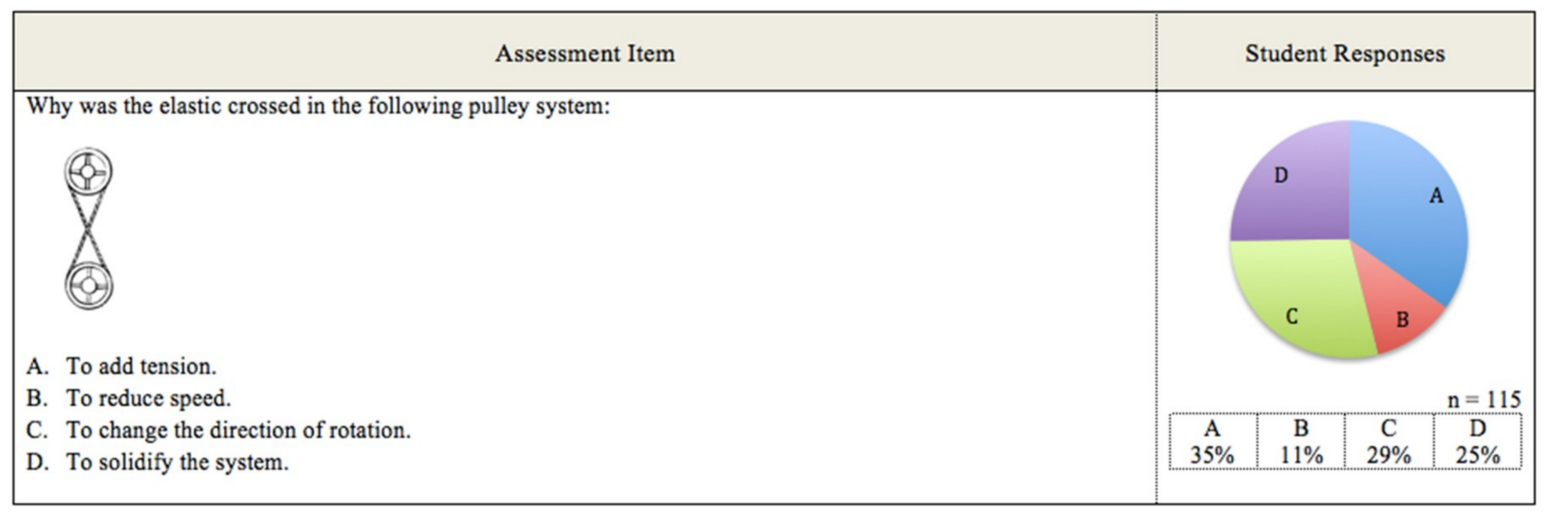

(a)

\begin{tabular}{|c|c|c|c|c|}
\hline Assessment Item & \multicolumn{4}{|c|}{ Student Responses } \\
\hline \multirow[t]{3}{*}{$\begin{array}{l}\text { Why are pulleys of different sizes used in a pulley system? } \\
\text { A. because they are the only ones available. } \\
\text { B. to change the tension. } \\
\text { C. to change the direction of the rotation. } \\
\text { D. to change the speed of the movement. }\end{array}$} & \multirow{2}{*}{\multicolumn{4}{|c|}{$\mathrm{n}=115$}} \\
\hline & & & & \\
\hline & $\begin{array}{c}\mathrm{A} \\
4 \%\end{array}$ & $\begin{array}{c}\mathrm{B} \\
43 \%\end{array}$ & $\begin{array}{c}\mathrm{C} \\
22 \%\end{array}$ & $\begin{array}{c}\mathrm{D} \\
31 \%\end{array}$ \\
\hline
\end{tabular}

(b)

Figure 6. Students' Notions of a Pulley System. (a) Arrangement of a Pulley System; (b) Pulley Size.

\subsection{Intuitive Notions of Force and Motion in Technological Design}

The QEP science and technology curriculum seeks to develop students' understanding of the effects of forces on simple machines and the "mechanisms that transmit motion (e.g. gears, pulleys, endless screw) and those that bring about a change in motion (e.g. cams, connecting rods)" [5] (p. 247). Learning about forces and different types of motion would enable students to understand how simple machines work. We used the following items to elicit students' initial ideas about forces and motion in relation to technical objects and simple machines.

One item asked the students to identify the forces applied by the user when using pliers (see Figure 7a). The majority of the students (85\%) correctly identified the forces that are used on the pliers. Students own experiences with scissors and pliers may have contributed to their understanding. Students were also asked to identify the path of a tip when closing the pliers (see Figure 7b). Students' responses revealed their struggle with identifying the path of the tip as shown below. Only one-fourth of the students were able to visualize the curved path of the tip.

Secondary students in grades seven and eight are expected to develop a qualitative understanding of the concept of mechanical advantage that different simple machines offer (see Figure 8). The following question asked students to determine the set-up that would provide the best mechanical advantage. Less than one-half of the students responded correctly. Additionally, students' responses to items focusing on different types of motion elicited their alternative ideas. For example, when asked to identity rectilinear/translation motion in some real-life situations, some students (17\%) thought that a child on a swing is moving in a straight line (see Figure 9). It is also interesting that $33 \%$ of the students did not think that the movement of an elevator is in a straight line. 


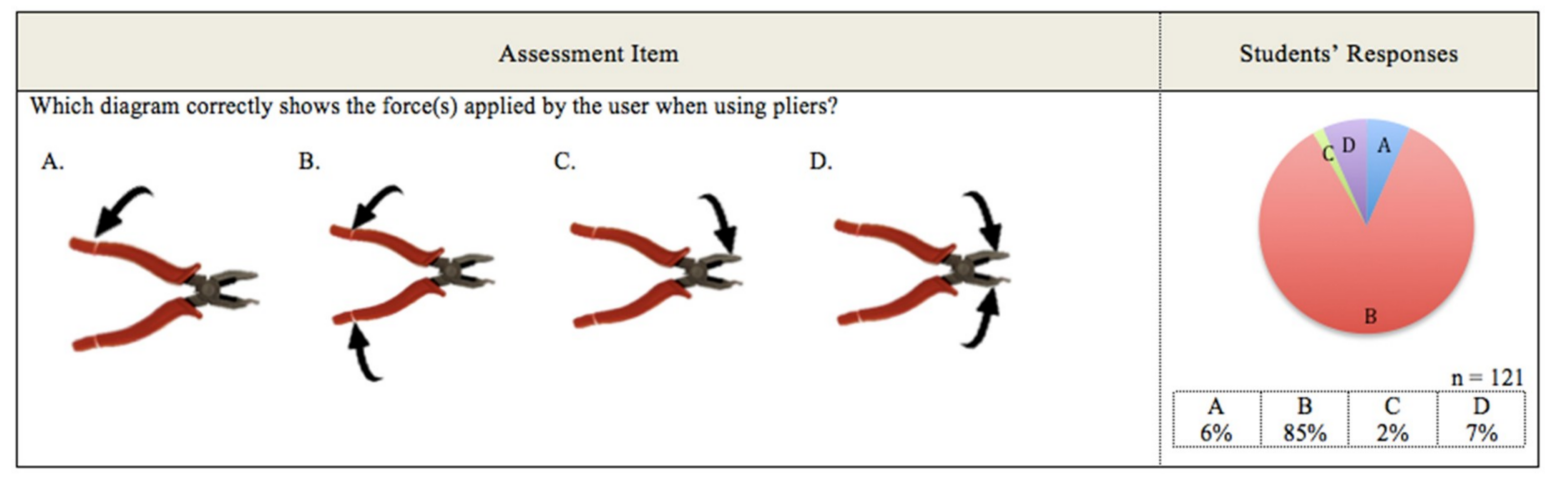

(a)

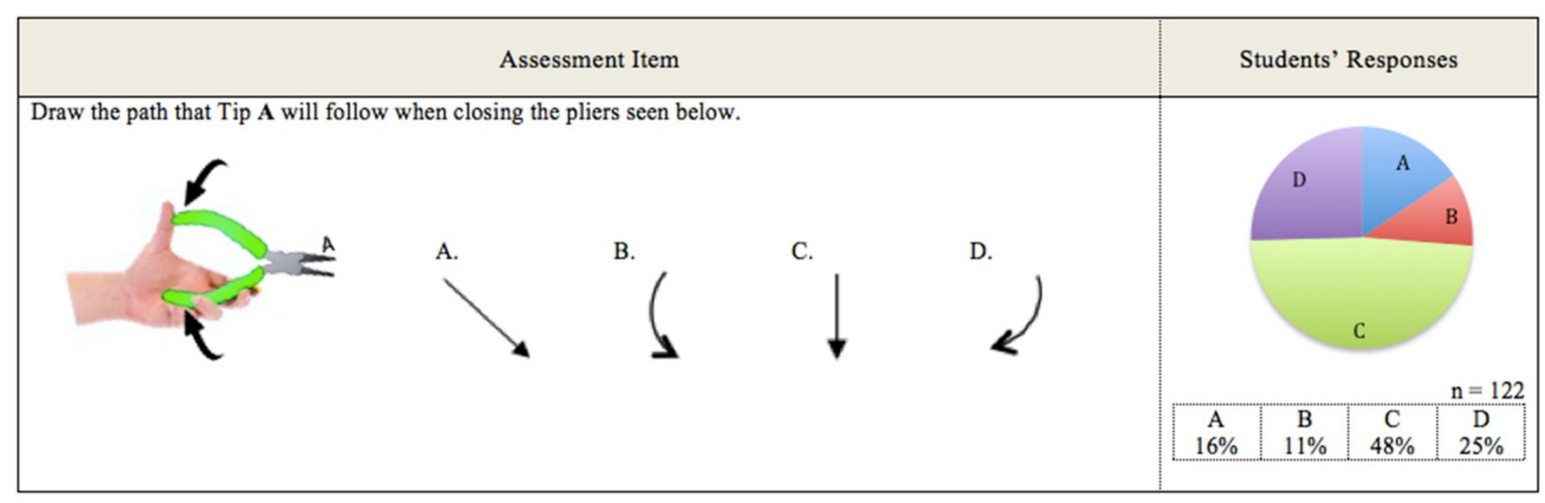

(b)

Figure 7. Students' Notions of Force and Motion in Technological Design. (a) Forces Acting on Pliers; (b) Direction of Movement in a Plier System.

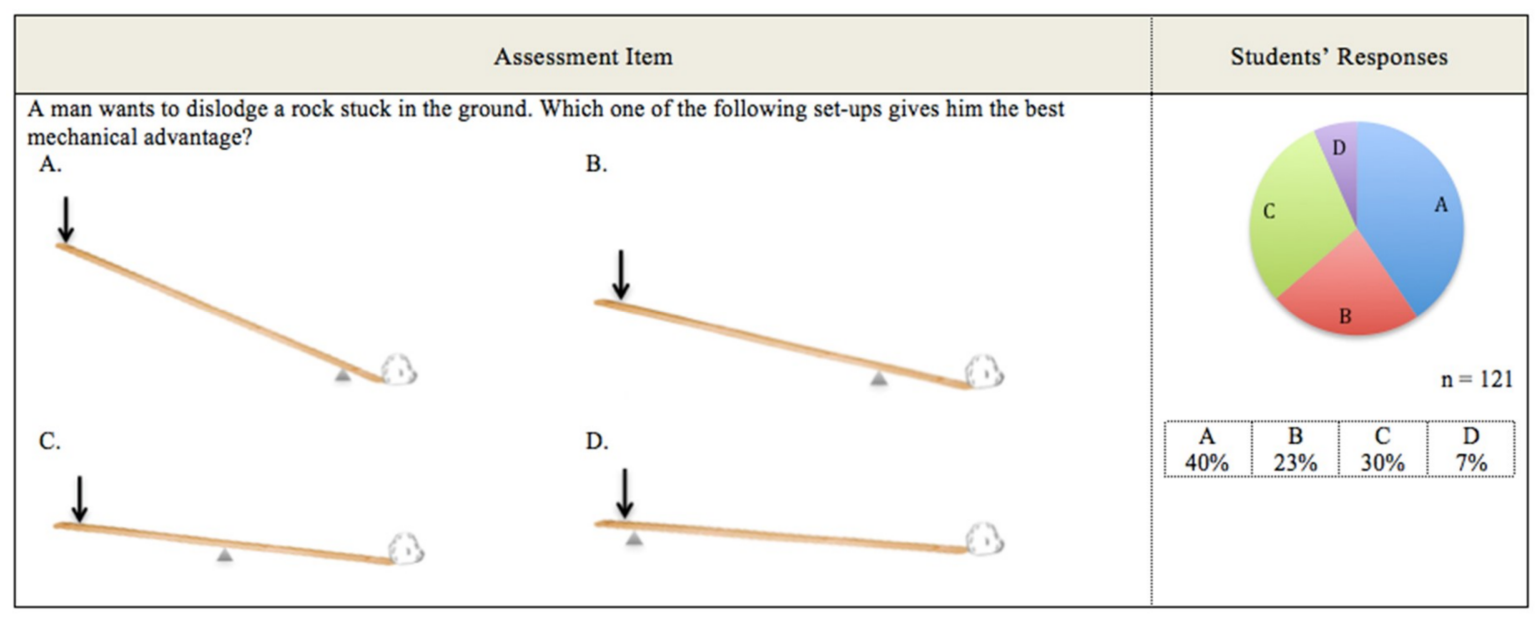

Figure 8. Students' Notions of Mechanical Advantage in Technological Design. 


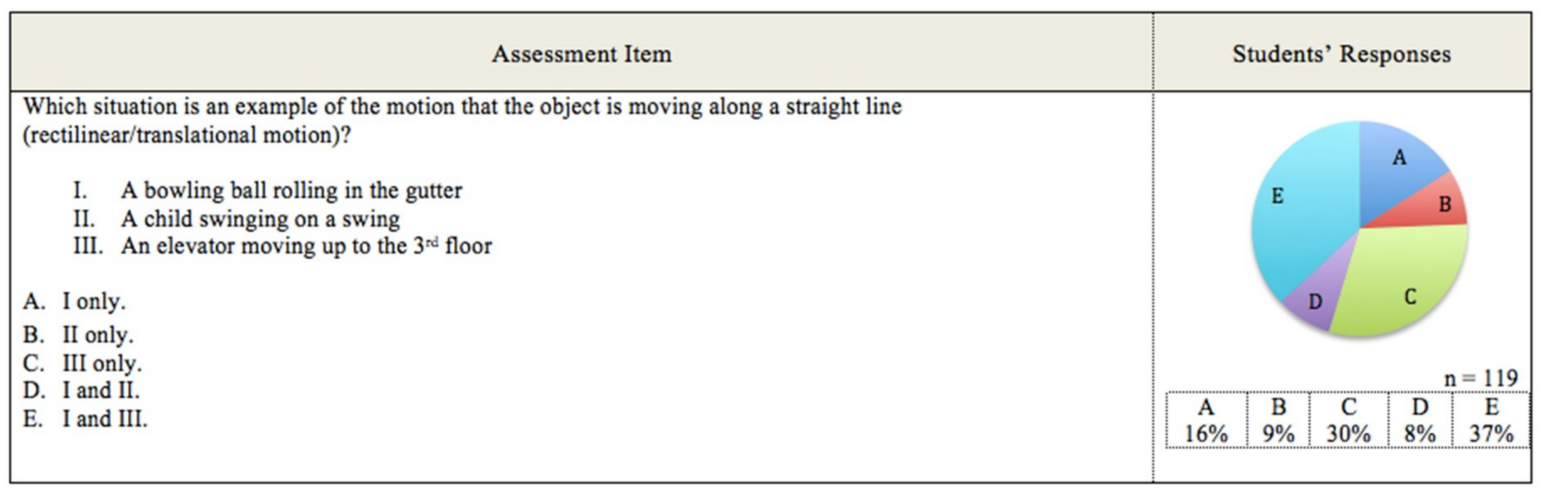

Figure 9. Students' Notions of Rectilinear/Translation Motion.

When asked to indicate an example of rotational motion, $23 \%$ of the students thought that a child sliding down a hill is exhibiting rotational motion (see Figure 10). Although approximately one-half of the students identified the Ferris Wheel as an example of rotational motion, many students $(70 \%)$, did not think of the motion of a swing as rotational motion. While $36 \%$ of the students identified the movement of a bicycle's frame as translational motion, approximately $64 \%$ described it as only rotational or helicoidal motion (see Figure 11). A bicycle is a complex technological system and teachers can use it to elicit their students' understanding of the movement of different parts of a bicycle.

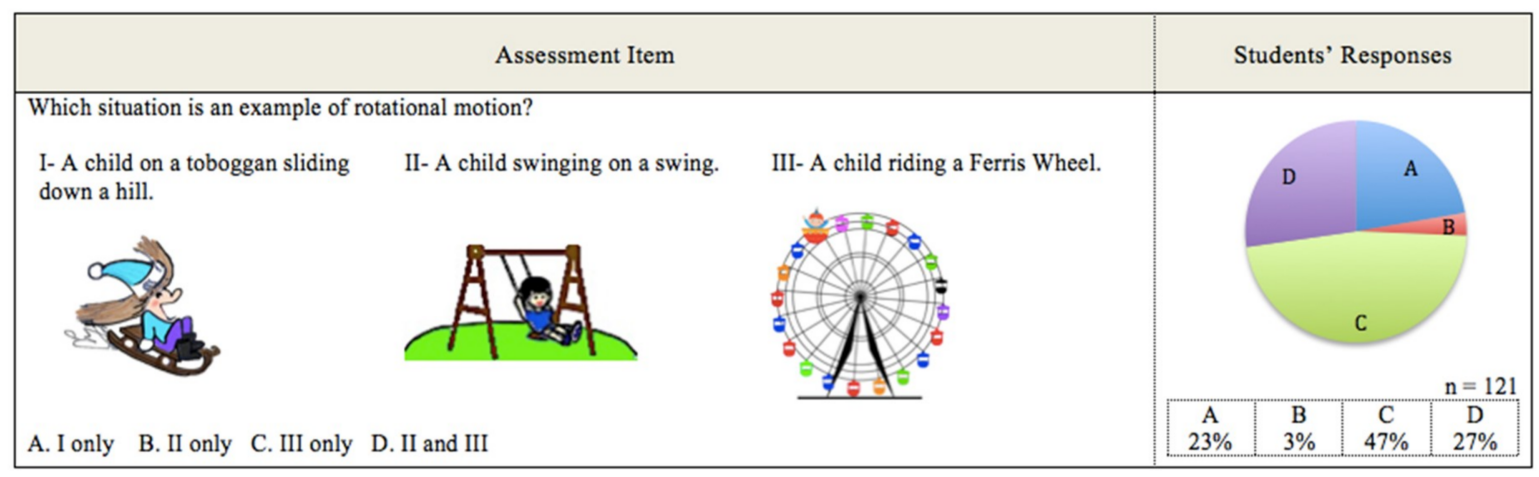

Figure 10. Students' Notions of Rotational Motion.

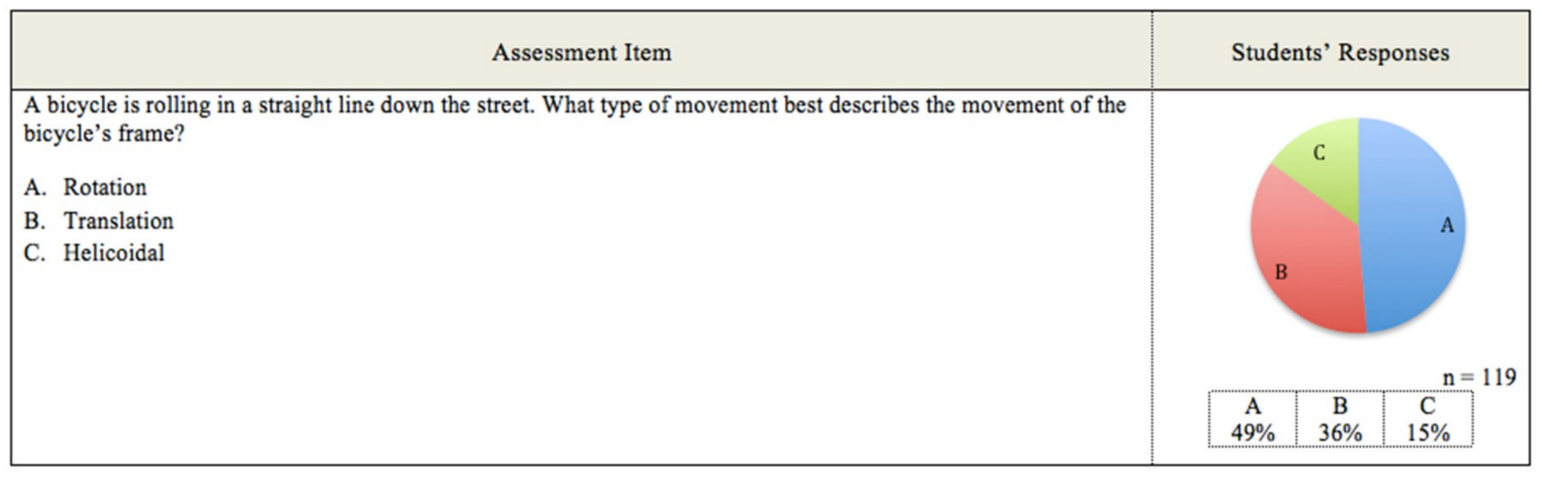

Figure 11. Students' Notions of Motion in Technological Design.

\section{Discussion and Implications for Pedagogy}

Our analysis revealed that students had a number of alternative ideas about basic concepts of technology. For example, some students did not understand the difference between the objects that exist naturally and those that are designed by human beings. Furthermore, many students thought that only electronic devices, such as a smart phone, are technical objects, whereas commonly used 
technical objects in our daily lives are not considered technological products. It seems that students' intuitive perception of technology is influenced by the pervasive use of electronic devices, as many students believed that technical objects need electricity. The majority of these students were intuitively able to understand and make correct predictions about the motion of gears. However, many students had alternative conceptions about the rotational speed of a gear set. While less than one-third of the students understood that the purpose of using different sizes of pulleys in a pulley system is to change the speed of the movement. Nevertheless, the majority of the students were not able understand the relationship between the pulley size and speed. At the same time, many students had alternative conceptions about the concept of mechanical advantage. The findings also suggest that students had difficulties in identifying the differences between different types of motion, such as rectilinear/translation motion and rotational motion. Science and technology teachers need to carefully consider these alternative conceptions while designing and teaching their lessons.

As noted earlier, based on the vast literature on children's intuitive conceptions and conceptual change approach to science teaching, it is critically important for science educators to elicit and carefully consider the intuitive ideas and conceptual resources that their students bring to learning situations to construct meaningful science learning experiences for students. As diSessa points out, ignoring students' conceptions and "sense of mechanism in instruction" creates an unwarranted wall between prior knowledge and scientific understanding," which may lead to alienation of students [23] (p. 206).

As discussed earlier, students' existing conceptions seem to be fairly stable and may co-exist with the scientific models that they learn through formal science instruction. Mounting evidence for the co-existence of alternative and scientific conceptions suggests that "abandoning or altering initial conceptions might not necessarily happen during conceptual learning" [38] (p. 57). Thus, instead of using the "conceptual replacement" approach, science educators need to focus on strengthening students' understanding of accepted scientific models and supporting students in carefully considering and choosing contextually appropriate models to solve problems [35] (p. 389). Dawson suggests that developing learners" "metacognitive abilities" is key to this process [35]. As Dawson explains:

. . . learners must be made aware that different interpretations of a situation may be possible. They then actively contrast different views by deciding what each would say about a set of phenomena, comparing these predictions and, where possible, testing them against actual outcomes. Importantly, this step is aimed at keeping the views differentiated, with the sphere of application of each being explored and practised. This step aims to develop the metacognitive abilities to select the appropriate view for the context, and inhibit any others, for, as Duschl and Hamilton (1998) concluded from their review of literature, from both the history and philosophy of science and from psychological perspectives, context is fundamental when one is considering new learning and its application. [35] (p. 410)

The conceptual change model proposed by Posner and colleagues $[53,54]$ also recognizes the resilience of children's prior conceptions and focuses on meaningful changes in their prior conceptions by testing them while solving problems, thereby assessing the strengths and limitations of their intuitive conceptions in terms of learning the scientific conceptions, and applying the concepts to comprehend and solve problems. Thus, students must be consciously aware of their intuitive conceptions in the face of complex problem-solving challenges, and use the scientific models to explain, predict, and solve problems $[28,34]$.

Building on this approach, Windschitl and colleagues recommend the model-based inquiry (MBI) approach to engage learners in sharing, testing, and revising their intuitive explanatory models through scientific inquiries [55] (p. 941). The model-based inquiry approach focuses on encouraging students to examine their explanatory models based on evidence, assessing their models in terms of their explanatory adequacy and predictive power, evaluating these models using criteria such as accuracy and plausibility, refining and modifying the explanatory models, and using them to solve new problems [55,56]. Importantly, the model-based inquiry approach emphasizes deep connections between scientific models and processes and the nature of science [57] (p. 42). Engaging students to 
deeply reflect on their intuitive understandings in relation to accepted scientific concepts may facilitate conceptual change. More specifically, during scientific investigations, students should be encouraged to challenge their intuitive ideas by testing their hypotheses, developing evidence-based explanations by carefully considering the data that they have collected, and deliberatively engaging with their explanations in relation to the accepted models [58-60]. As such, authentic scientific and technology inquiries in school science can facilitate active construction and application of scientific knowledge, and also promote a meaningful "understanding of the nature of science" [55] (pp. 944-945).

Several instructional strategies to promote conceptual change have been reported in the literature, such as discrepant events to expose the limitations of students' existing models, problem-based learning approaches, and inquiry-based activities to foster student engagement in the active construction of their knowledge $[28,34,59]$. Evidence suggests that active engagement of students in problem-based STEM inquiries is crucial for developing a deeper understanding of accepted scientific and technological models through inquiry, exploration, and application of knowledge [37,46,61-64]. Sanger and Greenbow (2000) conducted a study with introductory college chemistry students using the conceptual change model developed by Posner and colleagues to look at the impact of this instructional approach on students' alternative conceptions about the flow of electrons in aqueous solutions of electrochemical cells [65]. Students in the conceptual change instruction group were given the opportunity to discuss and test some prevalent alternative explanations about these concepts as well as the scientifically accepted explanation using experimental demonstrations. This study showed that the conceptual change instruction was effective in addressing students' intuitive notions. Similarly, Weaver's (1998) study with elementary and secondary students showed that collaborative hands-on experiments combined with dialogue, discussion, and deep reflection on learning can promote conceptual change. $\mathrm{K}-12$, and even college students, face difficulties in distinguishing between pure substances, heterogeneous mixtures, or homogeneous mixtures [66,67]. González-Gómez and colleagues (2017) carried out a study with elementary students to investigate the efficacy of conceptual change and laboratory instruction on these intuitive ideas. Students' intuitive models were elicited using a pre-test to inform subsequent instruction [66]. An interactive presentation on these concepts was followed by a hands-on lab session in which students worked in small groups to classify various materials, prepared different homogeneous or heterogeneous mixtures classify, and recorded their observations. The teacher guided the students to compare their initial knowledge with scientific explanations. In this process, students recognized that they needed to adapt their intuitive conceptions to develop a coherent scientific model to understand the composition of matter. The researchers argue that the conceptual change instructional approach is useful in promoting the construction and application of scientific models. Thus, teachers need to carefully select effective interventions that address students' alternative conceptions $[28,63,64]$.

Based on this literature and our work with science and technology teachers during this project, we share the following steps that teachers can use to foster their students' engagement and learning in STEM. Teachers can use these assessment questions to inform instruction to facilitate the development of a deeper understanding of accepted scientific concepts in students. In particular, the intuitive conceptions that we discovered around technology, technical objects, and simple machines during this study provide useful information to teachers to develop and adapt specific activities to address their students' alternative conceptions about these foundational technology concepts.

- Elicit students' prior knowledge and initial ideas about natural and technological phenomena.

- Discuss students' responses with them and probe their ideas further to encourage them to articulate and share their explanatory frameworks.

- Encourage students to attend to each other's ideas and explanations.

- Choose appropriate inquiry-based activities to address students' alternative conceptions.

- Engage students in inquiries that encourage them to solve specific problems related to technological systems by asking questions, designing experiments to test their hypotheses, collecting data, and developing evidence-based explanations through making sense of data. 
For example, teachers can encourage students to work with actual technical objects and simple machines to identify their functional components, represent the organization and operation of different components through visual diagrams, analyze the effects of forces acting on different parts of simple machines, and look at the mechanisms that transmit motion.

- Support students to compare their intuitive explanatory frameworks to accepted scientific and technological models.

- Provide a wide range of opportunities in different contexts to encourage students to apply their emerging understandings of scientific and technological models.

Given the paucity of research on alternative conceptions of technology, this study has explored middle school students' notions of basic technology concepts. Developing the assessment items to examine these foundational concepts entailed considerable effort on the part of the project team. Therefore, we were not able to explore advanced technology and engineering design related concepts. We only used the multiple-choice assessment questions in this study due to time and curricular constraints in science classrooms. Other creative assessment strategies, such as students' drawings, demonstrations, and think-aloud interviews with individual or small groups of students were not employed. It is important that future studies investigate the sophisticated and complex concepts included in the technology curriculum. Science educators and researchers can work collaboratively to develop a comprehensive tool using different assessment formats to explore students' ideas about all the technology concepts that are included in K-12 science curricula. Future research also needs to focus on the effectiveness of interventions that target technology and engineering concepts.

Author Contributions: A.A.'s contribution entailed conceptualization, literature review, funding acquisition, supervision, article writing and editing. Y.-S.H. assisted with data collection and analysis, literature review, and co-wrote the paper. K.E. contributed to the development of the assessment items, reviewed and wrote about the science and technology curriculum in Quebec and reviewed the drafts. Y.S. contributed to data analysis.

Funding: This research was funded by Ministère de l'Éducation et de l'Enseignement supérieur (MEES) Chantier 7 programme.

Acknowledgments: We thank our colleagues from Université du Québec à Montréal (UQAM) and McGill University who provided their insights and expertise that greatly assisted this work. We also thank Philip Ritchie and Jan Novak, members of the Science and Technology Implementation Committee (STIC) in Quebec, for assistance with the development of the items. We would also like to express our gratitude to the project team teachers and science consultants for sharing their pearls of wisdom with us during the course of this project.

Conflicts of Interest: The authors declare no conflict of interest. The funders had no role in the design of the study; in the collection, analyses, or interpretation of data; in the writing of the manuscript; or in the decision to publish the results.

\section{References}

1. Ministère de l'Éducation, du Loisir et du Sport. Québec Education Program: Secondary Cycle Two; Gouvernement du Québec, Bibliothèque et Archives nationales du Québec: Montréal, QC, Canada, 2007; ISBN 978-2-550-49674-8.

2. Ministère de l'Éducation, du Loisir et du Sport. Québec Education Program; Gouvernement du Québec, Bibliothèque nationales du Québec: Montréal, QC, Canada, 2001; ISBN 2-550-37958-6.

3. Charland, P.; Fournier, F.; Potvin, P. Apprendre et Enseigner la Technologie; MultiMondes: Montreal, QC, Canada, 2009.

4. Hasni, A.; Lenoir, Y.; Alessandra, F. Mandated interdisciplinarity in secondary school: The case of science, technology, and mathematics teachers in Quebec. Issues Interdiscip. Stud. 2015, 33, 144-180.

5. American Association for the Advcancement of Science. Science for All Americans: Project 2061; Oxford University Press: New York, NY, USA, 1993.

6. Council of Ministers of Education. Canada Common Framework of Science Learning Outcomes K to 12: Pan-Canadian Protocol for Collaboration on School Curriculum; Council of Ministers of Education: Toronto, ON, Canada, 1997. 
7. DeCoito, I. STEM education in Canada: A knowledge synthesis. Can. J. Sci. Math. Technol. Educ. 2016, 16, 114-128. [CrossRef]

8. Roth, W.M. Learning science through technological design. J. Res. Sci. Teach. 2001, 38, 768-790. [CrossRef]

9. Tala, S. Unified view of science and technology for education: Technoscience and technoscience education. Sci. Educ. 2009, 18, 275-298. [CrossRef]

10. Waight, N.; Abd-El-Khalick, F. Nature of Technology: Implications for design, development, and enactment of technological tools in school science classrooms. Int. J. Sci. Educ. 2012, 34, 2875-2905. [CrossRef]

11. Barma, S.; Guilbert, L. Different Visions de la Culture Scientifique et Technologique; Gouvernement du Québec, Bibliothèque nationales du Québec: Montréal, QC, Canada, 2006; ISBN 2-550-41725-9.

12. Ministère de l'Éducation, du Loisir et du Sport. Québec Education Program: Secondary Cycle Two; Gouvernement du Québec, Bibliothèque nationales du Québec: Montréal, QC, Canada, 2004; ISBN 2-550-42071-3.

13. Bolger, M.S.; Kobiela, M.; Weinberg, P.J.; Lehrer, R. Children's mechanistic reasoning. Cogn. Instr. 2012, 30, 170-206. [CrossRef]

14. DiGironimo, N. What is technology? Investigating student conceptions about the nature of technology. Int. J. Sci. Educ. 2011, 33, 1337-1352. [CrossRef]

15. Lehrer, R.; Schauble, L. Reasoning about structure and function: Children's conceptions of gears. J. Res. Sci. Teach. 1998, 35, 3-25. [CrossRef]

16. Brophy, S.; Klein, S.; Portsmore, M.; Rogers, C. Advancing engineering education in P-12 classrooms. J. Eng. Educ. 2008, 97, 369-387. [CrossRef]

17. Progression of Learning in Secondary School. Available online: http://www1.education.gouv.qc.ca/ progressionSecondaire/domaine_mathematique/science/index_en.asp?page=universTechnoligique (accessed on 15 November 2018).

18. Capobianco, B.M. Exploring a science teacher's uncertainty with integrating engineering design: An action research study. J. Sci. Teach. Educ. 2011, 22, 645-660. [CrossRef]

19. Driver, R. Students' conceptions and the learning of science. Int. J. Sci. Educ. 1989, 11, 481-490. [CrossRef]

20. Osborne, R.; Freyberg, P.S.; Bell, B. Learning in Science: The Implications of Children's Science; Heinemann: Auckland, New Zealand, 1985.

21. Yeo, S.; Zadnik, M. Introductory thermal concept evaluation: Assessing students' understanding. Phys. Teach. 2001, 39, 496-504. [CrossRef]

22. Babai, R.; Amsterdamer, A. The persistence of solid and liquid naive conceptions: A reaction time study. Int. J. Sci. Educ. Technol. 2008, 17, 553-559. [CrossRef]

23. DiSessa, A. Toward an epistemology of physics. Cogn. Instr. 1993, 10, 105-225. [CrossRef]

24. Driver, R.; Asoko, H.; Leach, J.; Scott, P.; Mortimer, E. Constructing scientific knowledge in the classroom. Educ. Res. 1994, 23, 5-12. [CrossRef]

25. Halloun, I.A.; Hestenes, D. The initial knowledge state of college physics students. Am. J. Phys. 1985, 53, 1043-1055. [CrossRef]

26. Peterson, R.F.; Treagust, D.F. Learning to teach primary science through problem-based learning. Sci. Educ. 1998, 82, 215-237. [CrossRef]

27. Baser, M. Fostering conceptual change by cognitive conflict based instruction on students' understanding of heat and temperature concepts. Eurasia J. Math. Sci. Technol. Educ. 2006, 2, 96-114. [CrossRef]

28. Potvin, P. Proposition for improving the classical models of conceptual change based on neuroeducational evidence: Conceptual prevalence. Neuroeducation 2013, 1, 16-43. [CrossRef]

29. Potvin, P.; Sauriol, É; Riopel, M. Experimental evidence of the superiority of the prevalence model of conceptual change over the classical models and repetition. J. Res. Sci. Teach. 2015, 52, 1082-1108. [CrossRef]

30. Duit, R.; Treagust, D.F. Conceptual change: A powerful framework for improving science teaching and learning. Int. J. Sci. Educ. 2003, 25, 671-688. [CrossRef]

31. Gilbert, J.K.; Osborne, R.J.; Fensham, P.J. Children's science and its consequences for teaching. Sci. Educ. 1982, 66, 623-633. [CrossRef]

32. Liu, X.; Lesniak, K.M. Students' progression of understanding the matter concept from elementary to high school. Sci. Educ. 2005, 89, 433-450. [CrossRef]

33. Novak, J.D. Meaningful learning: The essential factor for conceptual change in limited or inappropriate propositional hierarchies leading to empowerment of learners. Sci. Educ. 2002, 86, 548-571. [CrossRef] 
34. Kang, H.; Scharmann, L.C.; Kang, S.; Noh, T. Cognitive conflict and situational interest as factors influencing conceptual change. Int. J. Environ. Sci. Educ. 2010, 5, 383-405.

35. Dawson, C. Towards a conceptual profile: Rethinking conceptual mediation in the light of recent cognitive and neuroscientific findings. Res. Sci. Educ. 2014, 44, 389-414. [CrossRef]

36. Eryilmaz, A. Effects of conceptual assignments and conceptual change discussions on students' misconceptions and achievement regarding force and motion. J. Res. Sci. Teach. 2002, 39, 1001-1015. [CrossRef]

37. Libarkin, J.C.; Anderson, S.W. Assessment of learning in entry-level geoscience courses: Results from the Geoscience Concept Inventory. J. Geosci. Educ. 2005, 53, 394-401. [CrossRef]

38. Potvin, P. The Coexistence claim and its possible implications for success in teaching for conceptual "change". Eur. J. Sci. Math. Educ. 2017, 5, 55-66.

39. Caravita, S.; Halldén, O. Re-framing the problem of conceptual change. Learn. Instr. 1994, 4, 89-111. [CrossRef]

40. National Research Council. Inquiry and the National Science Education Standards: A Guide for Teaching and Learning; National Academies Press: Washington, DC, USA, 2000.

41. Piaget, J. Part I: Cognitive development in children: Piaget development and learning. J. Res. Sci. Teach. 1964, 2, 176-186. [CrossRef]

42. Driver, R. Children's Ideas in Science; McGraw-Hill Education: Maidenhead, UK, 1985.

43. Harlen, W. Primary school science: The foundation of science education. Phys. Educ. 1987, $22,56-62$. [CrossRef]

44. Brook, A.; Briggs, H.; Driver, R. Aspects of Secondary Students' Understanding of the Particulate Nature of Matter; Centre for Studies in Science and Mathematics Education, University of Leeds: Leeds, UK, 1984.

45. Solomon, J. Learning about energy: How pupils think in two domains. Eur. J. Sci. Educ. 1983, 5, 49-59. [CrossRef]

46. Libarkin, J.C.; Asghar, A.; Crockett, C.; Sadler, P. Invisible misconceptions: Student understanding of ultraviolet and infrared radiation. Astron. Educ. Rev. 2011, 10, 010105-1-010105-12. [CrossRef]

47. Asghar, A.; Libarkin, J.C. Gravity, magnetism, and “down": Non-physics college students' conceptions of gravity. Sci. Educ. 2010, 19, 42.

48. Fetherstonhaugh, T.; Treagust, D.F. Students' understanding of light and its properties: Teaching to engender conceptual change. Sci. Educ. 1992, 76, 653-672. [CrossRef]

49. Liou, P.Y. Developing an instrument for assessing students' concepts of the nature of technology. Res. Sci. Technol. Educ. 2015, 33, 162-181. [CrossRef]

50. Capobianco, B.M.; Feldman, A. Repositioning teacher action research in science teacher education. J. Sci. Teach. Educ. 2010, 21, 909-915. [CrossRef]

51. Loiselle, B. Actualiser l'enseignement des sciences par l'apprentissage de la technologie. In Apprendre et Enseigner la Technologie: Regards Multiples; Éditions MultiMondes: Montreal, QC, Canada, 2009.

52. Williams, K. Gear Down for Speed; Polytechnic Institute of NYUL: New York, NY, USA, 2009.

53. Posner, G.J.; Strike, K.A.; Hewson, P.W.; Gertzog, W.A. Accommodation of a scientific conception: Toward a theory of conceptual change. Sci. Educ. 1982, 66, 211-227. [CrossRef]

54. Strike, K.A.; Posner, G.J. A revisionist theory of conceptual change. In Philosophy of Science, Cognitive Psychology, and Educational Theory and Practice; State University of New York Press: Albany, NY, USA, 1992; pp. 176-185.

55. Windschitl, M.; Thompson, J.; Braaten, M. Beyond the scientific method: Model-based inquiry as a new paradigm of preference for school science investigations. Sci. Educ. 2008, 92, 941-967. [CrossRef]

56. Schwarz, C.V.; White, B.Y. Metamodeling knowledge: Developing students' understanding of scientific modeling. Cogn. Instr. 2005, 23, 165-205. [CrossRef]

57. Neilson, D.; Campbell, T.; Allred, B. Model-based inquiry. Sci. Teach. 2010, 77, 38.

58. Chinn, C.A.; Brewer, W.F. The role of anomalous data in knowledge acquisition: A theoretical framework and implications for science instruction. Rev. Educ. Res. 1993, 63, 1-49. [CrossRef]

59. Weaver, G.C. Strategies in K-12 science instruction to promote conceptual change. Sci. Educ. 1998, 82, 455-472. [CrossRef]

60. Windschitl, M.; Andre, T. Using computer simulations to enhance conceptual change: The roles of constructivist instruction and student epistemological beliefs. J. Res. Sci. Teach. 1998, 35, 145-160. [CrossRef] 
61. Millar, R. Analysing Practical Science Activities to Assess and Improve Their Effectiveness; Association for Science Education: Hatfield, UK, 2010.

62. Tao, P.K.; Gunstone, R.F. The process of conceptual change in force and motion during computer-supported physics instruction. J. Res. Sci. Teach. 1999, 36, 859-882. [CrossRef]

63. Harlen, W. Primary Science: Taking the Plunge. How to Teach Science More Effectively for Ages 5 to 12; Heinemann Publishing: Portsmouth, NH, USA, 2001.

64. Asghar, A.; Bean, S.; O'Neill, W.; Alters, B. Biological evolution in Canadian science curricula. Rep. Natl. Cent. Sci. Educ. 2015, 35, 1.1-1.21.

65. Sanger, M.J. Using particulate drawings to determine and improve students' conceptions of pure substances and mixtures. J. Chem. Educ. 2000, 77, 762-766. [CrossRef]

66. González-Gómez, D.; Airado-Rodríguez, D.; Acedo, M.A.D.; Niño, L.V.M. Change in elementary school students' misconceptions on material systems after a theoretical-practical instruction. Int. Electron. J. Elem. Educ. 2017, 9, 499-510.

67. Treagust, D.F.; Duit, R. Conceptual change: A discussion of theoretical, methodological and practical challenges for science education. Cult. Stud. Sci. Educ. 2008, 3, 297-328. [CrossRef]

(C) 2019 by the authors. Licensee MDPI, Basel, Switzerland. This article is an open access article distributed under the terms and conditions of the Creative Commons Attribution (CC BY) license (http:/ / creativecommons.org/licenses/by/4.0/). 